\title{
ECOLOGICAL ASPECTS OF WETLAND/GROUNDWATER RELATIONSHIPS IN SPAIN
}

\author{
F. González Bernáldez \\ Departamento de Ecología. Universidad Autónoma de Madrid. 28049 Madrid. Spain.
}

Keywords: Aquifer discharge habitats, Groundwater flow, Biological indicator, Phreatophyte, Wetland conservation

\begin{abstract}
Groundwater and sub-surficial water relationships are very important aspects of the ecological processes of Spanish wetlands. Although only a part of these relationships is known and a relatively small number of wetland types and geographical areas have been investigated, results indicate that geohydrology should be an essential part of wetland characterization. Hypogenic and epigenic wetlands are quite different categories of ecosystems and it has been established that groundwater relationships are key factors in determining flooding, water regime and level stability, hydrochemistry, basin origin and morphometry, turbidity, eutrophy, plant and animal communities and susceptibility to impact. Much closer cooperation between geohydrologists and wetland ecologists and better diffusion of ecological and hydrogeological knowledge among both groups of specialists are needed to cope with the important tasks of wetland management and conservation as well as to respond to new socioeconomic demands.
\end{abstract}

\section{INTRODUCTION}

Groundwater plays an important role in determining the ecological characteristics of many Spanish aquatic ecosystems although these circumstances have only been considered recently. There are several reasons for this lack of attention but the responsibility is shared by various professions. Hydrogeologists have traditionally paid little attention to surficial phenomena involving wetland-aquifer relationships. When they did show concern the aim of the project was usually to suppress loss of the groundwater reserve, thus considering water flow to the wetland as an obstacle and an economic problem to be solved.

Ecologists have also rarely been aware of the upward groundwater flows connected with many wetlands. They tended to believe that when water infiltrates deeply in the ground it is definitively lost by the surficial ecosystems and were unaware ignored that it may flow back again to the surface with new chemical characteristics.

In Spain, the seminal paper of R. Llamas (1982) on the neglected role of groundwater in wetland management and conservation has been very important in triggering research by various groups. This work has recently received more attention primarily due to the requirements of environmental impact studies.
Perhaps the catastrophic destruction of the Las Tablas de Daimiel National Park and the Ojos del Guadiana area due to excessive groundwater withdrawal was the event that finally increased both government and public awareness of the importance of groundwater systems in wetland conservation. This disastrous outcome had been accurately predicted in various internal reports, although little attention was paid to them by the authorities.

In the years preceding the Spanish Civil War, however, the Spanish ecologist Emilio Huguet del Villar y Serratacó, correctly interpreted many hydric soils and wetlands as the result of the action of upward moving groundwater flows (GONZALEZ BERNALDEZ, 1987). These interpretations based on extensive field experience were published at a time when the models establishing the principles of upward groundwater flow in unconfined aquifers (HUBBERT, 1940, TOTH 1965) had not yet appeared. At the time, it was generally believed that all the upward groundwater movements were due to "artesian" phenomena only possible in the special case of a confined aquifer. Del Villar's explanations therefore had to rely on discredited mechanisms such as the early interpretation of "plutonism", thus partly explaining the scarce repercussion of his theories.

Twenty years ago, there was a similar lack of attention to the effect of groundwater on wetlands in other coun- 
tries, although during the last two decades, research on groundwater-wetland relationships has been considerably developed in most advanced countries. One reason for this growing interest is also the generalization of Environmental Impact Statements that forced many geohydrologists to tackle the complicated problems of groundwater influences on wetlands. This is the case of Canada, where the extraordinary progress of the applications of geohydrology to wetland conservation is mainly due to the Government's policy of financing private conservationist groups for selecting experts who are asked to duplicate the developer's impact study. Excellent studies on wetland-groundwater relationships are presently carried out in the USA (WINTER, 1981) and in Holland (GROOTJANS, 1985).

\section{GENERALITIES}

The most important variables in wetland-groundwater relationships include the following:

- The nature of the aquifer or saturated material involved.

- The substratum's permeability.

- The groundwater flow characteristics: e.g., length and residence time of the water.

- The hydrochemistry and lithological characteristics of the territory.

- The relations between the different inputs: groundwater, meteoric water and exogenous water brought by inflowing water courses.

Groundwater inputs may be important enough to constitute significative components of the waterbody balance. In contrast, they may be negligible from the point of view of net water balance but be an important factor by preventing surface water infiltration as a result of the substrate saturation. Del Villar (GONZALEZ BERNALDEZ, 1987) mentioned upward moving groundwater as the most effective cause of the so called "impeded drainage".

These inputs normally depend on the permeability of the geologic materials in which the waterbody is confined. The most important and concentrated inputs are generally found in karst environments or in heavily fissured ground where groundwater flows through fractures and joints. The bottom of waterbodies on coarse sand such as dune slacks is also highly permeable.

The nature of the waterbody bottom is very important in controlling permeability. Small lakes formed by dissolution in hard, relatively pure limestone are carpeted by silt or "decalcification clays" flocculated by the influence of Ca ions. These waterbodies behave as "piezometric lakes" promptly transducing piezometric fluctuations of the aquifer with which they are connected ("torcas", Cuenca). In contrast, waterbodies located on detritic siliceous Miocene sediments in both Central Subplateaus are often affected by alkaline groundwater provoking clay dispersion and impermeable bottoms that respond to piezometric fluctuations with a considerable time lag.

The same examples can illustrate the effects of groundwater hydrochemistry. Detritic siliceous Miocene sediments, poor in $\mathrm{Ca}$, permit the observation of the progressive "ageing" process of groundwater when its flows become longer and residence time within the sediments increases. Groundwater becomes increasingly alkaline when moving towards the lowest parts of the aquifer, thus influencing the hydrochemistry, sediment flocculation and the kind of organisms of the wetlands affected by its discharge (GONZALEZ BERNALDEZ et al., 1989). In contrast, areas in which $\mathrm{Ca}$ is dominant may induce rapid changes in infiltrated water chemistry and the evolution process is very short and barely noticeable (FREEZE \& CHERRY, 1979).

The relationship between meteoric and groundwater inputs is also important. Very often, groundwater seepage to wetlands is a stabilization factor, regulating water level and ensuring flooding persistence even in areas characterized by the Mediterranean summer dry period. Water level fluctuations and flooding duration are related to the nature of aquatic biocenoses that can be used as indicators of average water regime and groundwater relationships (GONZALEZ BERNALDEZ et al., 1988). Maximum water level stability is achieved in wetlands receiving regional flows from large aquifers while the buffering effect may be incomplete (GONZALEZ BERNALDEZ et al., 1992a) in other instances (connection with small volumes of saturated ground, low capacity detritic sediments such as aeolian sands or thin outwash deposits such as "rañas") .

The particularities of wetland-groundwater relationships are better considered in the framework of the following typology.

\section{WETLAND TYPOLOGY AND CHARACTERISTICS FROM THE POINT OF VIEW OF GROUNDWATER RELATIONSHIPS}

The following tentative types can be considered: 


\section{Maritime wetlands}

Both in coastal salt marches influenced by tides and in Mediterranean areas tlooded by autumn storms. the effects of upward continental groundwater flows are generally noticeable. Ground saturated by continental flows can lengthen the flooding period, resulting in complex mixture patterns. Continental groundwater and sea water interactions are especially complex in the case of complicated fluviomarine formations such as deltas (Delta del Ebro, Tarragona; Llobregat, Barcelona; Tinto and Odiel, Huelva, etc.).

\section{Fluviomarine deltas}

Natural or less modified deltas are made up of heterogeneous territories in which either continental or maritime influences predominate. Tidal and brackish water influences dominate in the lowest, distal reaches of the delta while continental groundwater and watercourses are important in the highest parts. Most deltas were important aquifers on the surface of which areas of groundwater discharge, waterbodies and channels alternated with areas of raised ground and levées. The upper parts were characterized by barely mineralized water while the lowest reaches were normally heavily saline. Part of the lakes and lower channels were affected by tide water and a transition area of intermediate salinity was located betwcen the maritime and continental zones of influence.

Before recent profound alteration, these effects were clearly visible in the Doñana area (S.W. Spain). There was sharp contrast between the less mineralized "lucios altos" (waterbodies of the upper reaches), upper "caños" (channels), dune slack ponds and the heavily mineralized "lucios bajos" (waterbodies of the lower reaches). Hydrochemical complexity was increased by the interaction between the water carried by exogenous water courses and channels, the inflowing groundwater and the brackish water from tides. Gradients of salinity and differences in water regime were very important in conditioning animal behaviour rhythms, including migrations. It is known that a given level of salinity and flooding in intermediate "lucios" was necessary for geese to feed on bulrush rhizomes (Scirpus maritimus subsp. compactus) and that seasonal connections between the different channels and waterbodies controlled fish migrations. Very often, complex sediment stratification in deltas, including alternated permeable and impermeable layers, add more variable influences to this complexity by diversifying the origin and characteristics of the inflowing groundwater.

\section{Riverine wetlands and floodplains}

These wetlands have also been profoundly altered in most developed countries, especially by river regulation and in some cases by excesive groundwater extraction.

Large water courses flowing on very flat plains help to flood extensive areas but the main reason for braiding and permanent flooding ("tablas") is the presence of diffuse groundwater discharges that ensure substratum impermeability. The role of groundwater in these ecosystems was clearly shown in the destruction of the Tablas de Daimiel National Park (Ciudad Real) affected by excesive groundwater withdrawal. The resulting damage is attributed to the loss of the aquifer influences that controlied the regime and chemistry of the water and maintained an impervious, saturated substrate preventing the infiltration of surficial water.

The disturbance of the Tablas de Daimiel natural area started in the 1960's with the irrigation of a rapidly increasing area. Today most of the water used for the irrigation of the $150.000 \mathrm{ha}$. farming area comes from the $6000 \mathrm{~km}^{2}$ aquifer that was formerly responsible for tlooding the Tablas. About 15.000 wells withdraw 600 cubic hectometer/year and have lowered the upper limit of the saturated zone by as much as 30 metres. As a result, the flood-plain jointly made up of the Guadiana-Cigüela junction and the important groundwater systems has been profoundly altered and groundwater inflow completely suppressed. As the groundwater no longer saturates the Tablas bottom, the surface waters infiltrate deeply and do not form the extensive flooded areas characteristic of this wetland. The former discharge wetland has now been converted into a recharge area. Therefore, the costly attempts to solve the problem by bringing water through the TagusSegura channel also result in infiltration and in aquifer recharge. Ironically, this infiltrated water is finally pumped into the wells and used for irrigation.

In order to reduce water losses, the former exorheic system that maintained an appreciable water flow has now been converted into a closed system by damming the outlet. As a result, and also owing to the lack of the less mineralized groundwater inputs, salination has increased. Water quality changes, turbidity increases and the depression of the saturated zone have all brought about important changes in vegetation. The Myriophillaceae, Potamogeton spp., Charophytes and other submerged plants carpeting the ground are greatly diminished and the water-stress sensitive Cladium mariscus is been steadily replaced by the more resistant Phragmites australis. These changes are affecting animal communities, including the most important objecti- 
ves of the conservation policy such as the red crested pochard Netta rufina (LLAMAS, 1988).

Even much simpler ecosystems than the conventional floodplains such as the "vegas" of the Cigüela River have been recently destroyed in Spain. These "vega" areas located upstrearn of the Tablas de Daimiel were periodically flooded by the Cigüela with the important contribution of diffuse groundwater discharges that maintained a saturated ground. At present, only some vestiges remain such as the El Masegar and El Taray private estates (Toledo) where the flooded condition is ensured by artificial groundwater pumping. The absence of natural flooding by river water is due to the excavation and drainage of the Cigüela stream channel, even in its upper reaches, thus resulting in the loss of the natural values of the "vegas". This work carried out in the 1980's when all governments of the world were already aware of the importance of wetland conservation is one of the most gratuitous and harmful outrages against natural values in modern Spain.

\section{Peririverine wetlands}

Floodplains in their simplest form, floodable "vegas" are part of a continuum of riverine wetland types in which the role of groundwater is always important. Oxbow lakes ("madres viejas", "galachos") and backwaters or flooded depressions between the natural levee and the terrace system ("derrames", "cilancos") are very much influenced by natural groundwater systems. Oxbow lakes are flooded by groundwater from the same aquifer flowing into the usually "gaining" stream. "Backwaters" and other peririverine lakes originate during floods but they persist for longed periods due to the lack of vertical drainage induced by upward vertical components of groundwater flow (examples: "madres viejas" or oxbows of the Jarama river, near Madrid; "galachos" of the Ebro river, near Zaragoza).

Ecosystems related to river floods and influenced by groundwater were very important prior to river regulation (in Spain, for instance, they were the favoured locality of the now extinct sedentary crane populations). Today the numerous gravel and sand pits resulting from mining operations on river terraces and flooded by groundwater from the alluvial aquifer can be restored in order to imitate these lost habitats (DEPARTAMENTO DE ECOLOGIA, 1991).

\section{Hidden seepages and seeps}

In the hidden seepages. water from the saturated zone is evaporates directly to the atmosphere through soil micros- tructures (capillaries, colloids, etc.) or plant conducting systems. But no liquid water accumulates on the surface as in other wetlands. The upper limit of the saturated zone should be relatively close to the soil surface to permit this evapotranspiration process. The exact distance depends on soil texture and structure and on the size of the capillary zone, extending to 3 meters or more under special circumstances. Some plant species, however, are able to extract and transpire groundwater from considerable depths. Mediterranean Tamarix species have been observed pumping groundwater at about 10 meters and depths of 20 to 30 meters have been recorded for some American Prosopis. Groundwater influence may profoundly affect soil chemistry and profile morphology inducing hydric, saline or alkaline conditions (GONZALEZ BERNALDEZ \& REY BENAYAS, 1992a) even if no liquid water accumulates on its surface.

Hidden seepages or seeps are important forms of aquifer discharge in semiarid areas, giving rise to characteristic landscape sectors and biocenoses. Seepages in the granite areas of the Sistema Central give, for instance, rise to the majority of wet meadows and peaty meadows ("chortales", "tollos") on fractured and altered granite. These wet surfaces are essential for grazing by livestock during the summer dry period. Acid meadows (Nardus stricta. Trifolium laevigatum, Juncus squarrosus, etc.) correspond to short tlows and short residence times of the groundwater. In contrast, meadows linked to longer flows, coming up from considerable depths and having long residence times are characterized by slightly alkaline conditions and high $\mathrm{pH}$ (Trifolium resupinatum, T. michelianum, Descharnpsia cespitosa subsp. refracta, etc.). Alkaline meadows are always located at lower altitudinal levels (lower pediments, granite outcrops in the plains) while acid meadows can be found everywhere (GONZALEZ BERNALDEZ, 1989b)

The interstitial meadows scattered through the vast cereal fields on both Castillian subplateaus ("prados entrepanados", "longares", "rodiles", "mangadas") are similar. They are due to evaporative discharges from the main aquifer at the botton of the thalwegs. They are often associated with creeks or small waterbodies in the center of the meadow. In siliceous deposits they tend to be saline or alkaline when located at the lowest levels of the aquifer (thus corresponding to the longest, regional flows).

Continental "saladares", areas where mineralized groundwater is evaporated and evaporite minerals accumulated on the surface or in the soil profile, normally correspond to "solonchak" soils (La Mancha, Monegros). Very often they are associated with more or less ephemeral saline 
lakes (continental discharge "sebkhas" or "playas", GONZALEZ BERNALDEZ, 1992). It has been observed that the lowering of the water table leads to the transformation of "playas" or "sebkhas" into non-floodable "saladar". Its salination depends on the distance of the soil surface from the upper level of the saturated zone. The vegetation cover reflects the rate of salinization, ground- . water fluctuation and hydrochemistry. There are, for instance, indicator plant differences between "soloniets" areas (where sodium is the dominant cation) characterized by a lower plant diversity and the absence of some species (for example, Limonium spp.) and the more biodiverse, calcium-rich "solonchak".

In areas with groundwater at a considerable depth, however, different temporarily flooded "saladar"-similar or "sebkha"-similar structures can be formed at the outlet or the confluence of wadis, "ramblas" or other runoff features. The floodable territory thus behaves like a recharge area. Under these circumstances, however, true salinization and halophytes can only occur in the truly arid zone. Halophytes are often absent, as in the Argentinian "barriales".

Wetlands in detritic siliceous facies, sand and siliceous outwash deposits

The detritic facies of the continental Miocene in central Spain offer many examples of these wetlands, although a large percentage of the variants connected with non-mineralized groundwater (upper reaches of the aquifer) have been altered or destroyed by groundwater withdrawal from the aquifer for irrigation purposes (GONZALEZ BERNALDEZ \& REY BENAYAS, 1992). The wetlands corresponding to the mineralized parts of the aquifer (including the interesting alkaline lakes of Coca, El Raso del Portillo near Boecillo, Valladolid, or the Villafáfila lakes) have also been subjected to serious disturbance by drainage attempts.

As already indicated, the main difference from the wetlands associated with limestone or marl (for instance the "chemical" facies of the continental Miocene) is the process of groundwater evolution in silicate aquifers leading to alkalinization, high $\mathrm{pH}$ (9 to 11 in some lakes), the presence of carbonate and the deposits of characteristic minerals such as "trona". But in addition to the wetlands connected with the regional aquifer, a wide range of other geohydrological circumstances can be observed, including recharge waterbodies exclusively dependent on meteoric water (GONZALEZ BERNALDEZ et al., 1988; BESTEIRO, 1992).
Most wetlands on silicate detritic materials occupy ancient depressions of fluvial origin, but it has been observed that upward moving groundwater and wind can be agents of lake-basin formation. Mud volcanos or "soapholes" (GONZALEZ BERNALDEZ et al.) are able to excavate depressions that can be extended by wind action. On the other hand, salination of the soil surface by groundwater may provoke the abscnce of plant cover, thus exposing the soil to wind erosion. Clusters of small saline waterbodies accompanied by sediment accumulation removed by wind ("clay dunes" or "lunettes") on the leeward side are characteristic of saline discharge areas (Raso de El Portillo, Valladolid; Lagunas de Villafáfila, Zamora). They probably represent initial stages of lake-basins (REY BENAYAS et al., 1989; GONZALEZ BERNALDEZ et al., 1987).

Wetlands associated with saturated zones in outwash deposits or "rañas" corresponding to small volume aquifers are always characterized by short flows and non-mineralized grounwater and have acidophilous vegetation belts (Nardus stricta, Juncus squarrosus, etc.). Outstanding examples are the Laguna de El Cristo, Laguna Cervera (Salamanca), and the Laguna Delgada (Toledo), with less acidophilous margins.

Water bodies in granitic areas are associated with the previously mentioned hidden seepages and correspond to the same hydrochemical relationships. The most determinant factor is their connection with differently evolved groundwater flows. They can vary from low mineralized water to hypersaline conditions such as the small ponds and springs found near large faults or contacts with other geological materials (for instance Miocene arkoses as in El Salobral,Toledo). The circumstances of the heavy salination of some groundwater discharges near the edges of the granite area are not clear. They probably correspond to the upward trajectories of very old, deep water (HERRERA, 1987). In contrast, groundwater evolution in the center of the granitic area only leads to slight alkalinization and mineralization.

Wetlands located on aeolian sands are remarkable for their high substratum permeability and their "piezometric" character. The small lakes on dune slacks in the Doñana area are very good examples. Water is poor in dissolved minerals, leading to acid and dystrophic conditions indicated by characteristic communities. However, sodium enrichment can occur in some instances (Laguna de Santa Olalla), probably due to groundwater flow interception by deposits containing soluble materials. 


\section{Wetlands in limestone areas}

A common characteristic of wetlands on limestone is the predominance of dissolution processes in the formation of lake basins. Aside from this factor, the ecological circumstances of wetlands on limestone are highly diverse, depending mainly on altitude and climate. The following cases summarize the major groundwater relationship patterns.

Karst: Karstification leads to huge concentrated flows of groundwater which are often responsible for permanent flooding even when outlets or emissaries are present. An example of karst wetlands are the Ojos de Villaverde (Albacete). Water level stability is indicated by the presence of peaty soils with Cladium mariscus and a mosaic of other typical vegetation of more fluctuating conditions in the areas less affected by the main discharge (Phragmites australis and Schoenus nigricans). The continulous water flow ensured by the outlet and the abundance of $\mathrm{Ca}$ ions leads to high water transparency, allowing the growth of an extensive carpet of Characeae. The same circumstances were typical of many wetlands in La Mancha characterized by flowing calciumbicarbonate water (Lagunas del Arquillo, Sanguijuela, etc.).

Subcircular waterbodies are frequent in relatively pure and hard limestone or in marls with a high calcium carbonate content from the Secondary period (Albacete, Cuenca, Aragón). Very often, grouridwater is an important agent in the origin of these cavities. Different modalities of suffosion mechanisms may be combined with other factors (for instance salinity and wind in the case of the steppe areas such as Los Monegros, Zaragoza).

Groundwater influences in these small lakes can be quite diverse. A typical case is the action of calcium-rich water in relatively pure limestone areas contributing to the formation of a highly permeable, flocculated "decalcification clay" bottom and high transparency (example Las Melchoras complex in Albacete). The permeable bottom allows the water table to fluctuate and even to expose the dry lake bottom without salt or evaporite deposits.

In marl containing evaporites, groundwater flows intercept soluble materials, creatirig salinity conditions even for very short groundwater flows and residence times. This is the case of many waterbodies in La Mancha and Aragon. Most of them are temporary, presenting the characteristics of a discharge "sebkha" with subaqeuous or interstitial evaporite formation during a part of the year (Lagunas de la Playa, Salineta, Peña Hueca, Tirez) but others are permanent due to their link with steady regional groundwater flows. This is the case of the hypersaline Laguna de Chiprana (Zaragoza).
Drainage restriction by upward moving groundwater in fine textured deposits and other phenomena (such as replacement of monovalent cations by ageing water) often lead to the formation of montmorillonite-rich vertisols (bujeos) with typical associated impondments (Examples: The Lantejuela-Ballestera complex, Sevilla or the temporary "lagunas" in La Sagra area, Toledo).

Wetlands in recharge areas and wetlands with no influence of groundwater

Several criteria can be used to differentiate waterbodies in discharge areas receiving the influence of groundwater flows from recharge waterbodies exclusively dependent on meteoric water (GONZALEZ BERNALDEZ et al., 1988; GONZALEZ BERNALDEZ et al., 1989c). In the forementioned siliceous detritic areas, discharge waterbodies tend to be less ephemeral, to exhibit at least a belt of true phreatophytes, to have more mineralized water and salt efflorescences on their margins and to be associated with typical discharge phenomena: mud volcanos, "lunettes" and saline or alkaline soils ("saladares", "salgüeros"), etc.

A water balance of the waterbody should, however, be carried out for more strict discrimination (BESTEIRO, 1992). The water regime of the wetland can be deduced from piezometric measurements, precipitation and evaporation records, water levels and out- os in-flowing water discharges. Although some of these measurements are difficult and not always very reliable, an approximate water balance is often achieved that can reveal the influence of groundwater inputs.

The water regime of a given wetland may be rather complex owing to the participation of surface runoff, inflowing and outflowing watercourses, net inputs due to inflowing groundwater and losses by internal seepage. All these factors may act simultaneously, the lake can lose water by underground seepage in certain areas of its bottom and at the same time receive net groundwater inputs through other areas. The gaining or losing state can alternate in time depending on water level in the lake or on particularities of the saturated zone geometry (WINTER, 1981).

In the semiarid Mediterranean region, wetlaiids receiving only meteoric water are always ephemeral. The extreme case of shallow rain pools with characteristic biocenoses adapted to short flooding periods are very important in dry regions.

The lack of connection with groundwater flows and the meteoric origin of the water may be suspected in the small 
Table 1. Plant indicators of groundwater chemistry: Corrected frequency profiles of discharge-habitat species as related to groundwater electrical conductivity, $\mu \mathrm{s} / \mathrm{cm}$. Only species with mutual information $\geq 0.1$ and corrected frequency $21.2(\mathrm{x} 100)$ are included (from GONZALEZ BERNALDEZ et al., 1989 a, modified). \pm signifies indifferent sensitivity to the factor class (corrected frecuency between 0.8 and 1.2).

Class intervals

$2.300 / 2.775 / 2.790 / 2.850 / 3.000 / 3.280$

Festuca ampla

Potentilla reptans

Ononis repens

Trifolium pratense

Plantago lanceolata

Juncus inflexus

Poa trivialis

Hieracium pilosella

Poa pratensis

Carex divisa

Trifolium fragiferum

Convolvulus arvensis

Agrostis castellana

Dactylis glomerata

Medicago sativa

Cichorium intybus

Hypochaeris radicata

Lolium perenne

Eryngium campestre

Galium verum

Cynosurus cristatus

Festuca arundinacea

Cynodon dactylon

Festuca rothmaleri

Alopecurus arundinaceus

Plantago maritima

Convolovulus lineatus

Juncus maritimus

Koeleria vallesiana

Artemisia coerulescens

Aeluropus littoralis
Scirpus holoschoenus

Suaeda vera

\section{5}

540

491

412

270

328

297

234

210

136

$\pm$

349

337

279

253

231

220

220

202

281

253

174

$\pm$

$\pm$

$\pm$

315

lakes located on recharge areas in the center of large interfluves. In the Tertiary deposits of the northern Castillian subplateau, these recharge waterbodies are often small (about $20 \mathrm{~m}$ diameter) and subcircular. They are characteristically associated in clusters in the center of the large interfluve (REY BENAYAS et al., 1989). Nothing is known about their origin or significance.
WATER BALANCE AND ITS RELATIONSHIP TO HYDROCHEMISTRY, GEOMORPHOLOGY, FLOODING REGIME AND OTHER WETLAND CHARACTERISTICS

The most interesting approach to wetland interpretation is the combination of hydrology with other aspects such as 

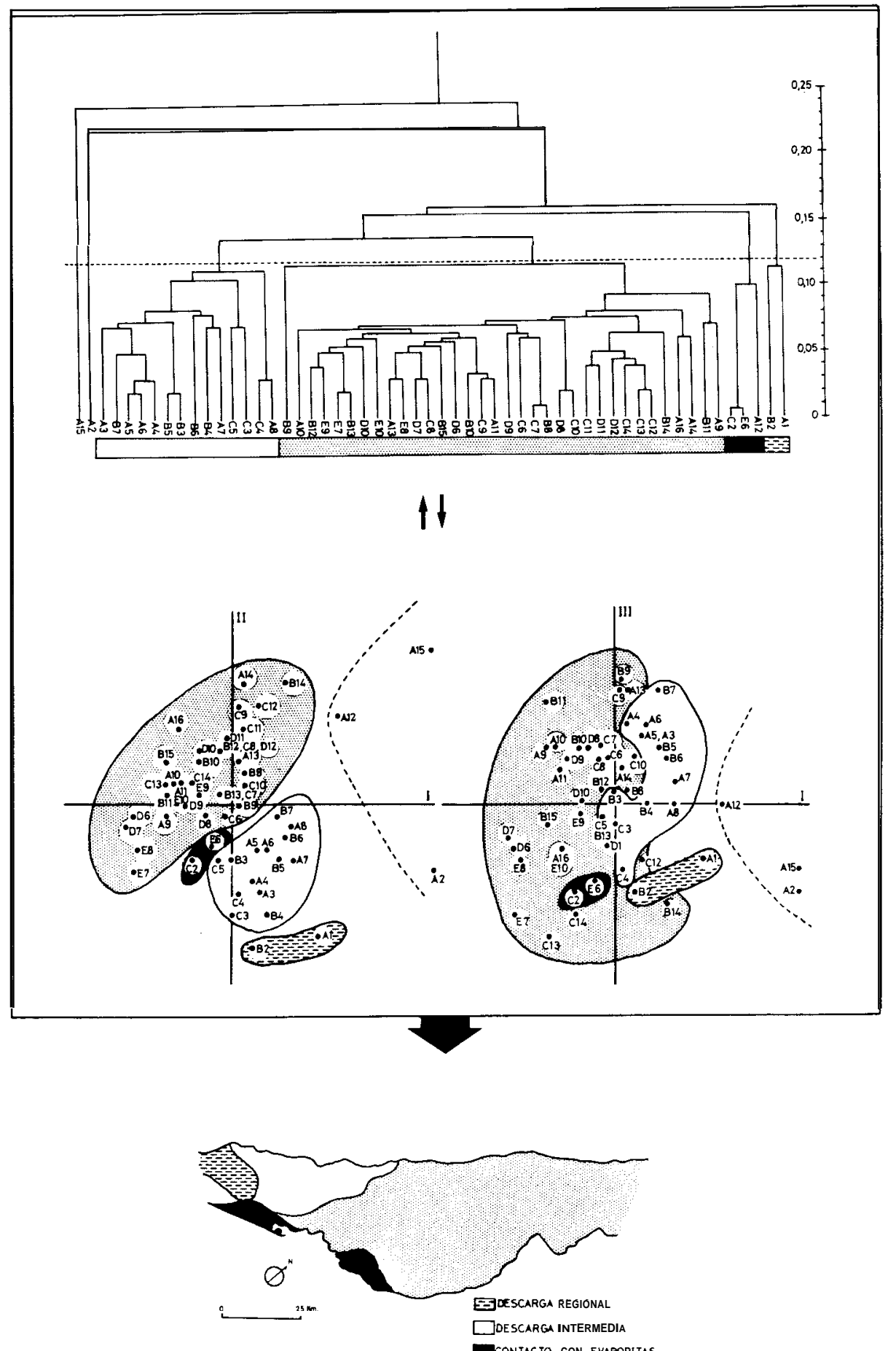

Dontacto con evaporitas

Đ

Figure 1. Relationships between multivariate classifications (clustering and factor analysis with overlaid clusters) of the Madrid aquifer wetlands using chemical, hydrological and topographic information and ita location in different aquifer sectors. There is an obvious close relationship between location on the aquifer surface and wetland characteristics (from BESTEIRO. 1992) 
lithology, geomorphology, hydrochemistry, biogeochemical cycles and biocenoloy. If the characterization is too narrow and based on a partial consideration of these aspects, the results may be misleading.

However, a number of studies on the Madrid Aquifer wetlands have shown the close relationships between hydro$\operatorname{logy}$ and other aspects of the ecological analysis of these wetlands. Figure 1 shows the importance of the different aquifer sectors (established with hydrogeological criteria) and their relationships with wetland classification. There is a clear correspondence between the hydrogeological criteria and the combination of a large number of ecological variables used in the cluster classification.

Figure 2 illustrates the close relationships between groundwater evolution trends and the aquifer sectors.

The water balance is one the most difficult and timeconsuming tasks in wetland characterization. Although preliminary interpretation and diagnoses for wetland mana-

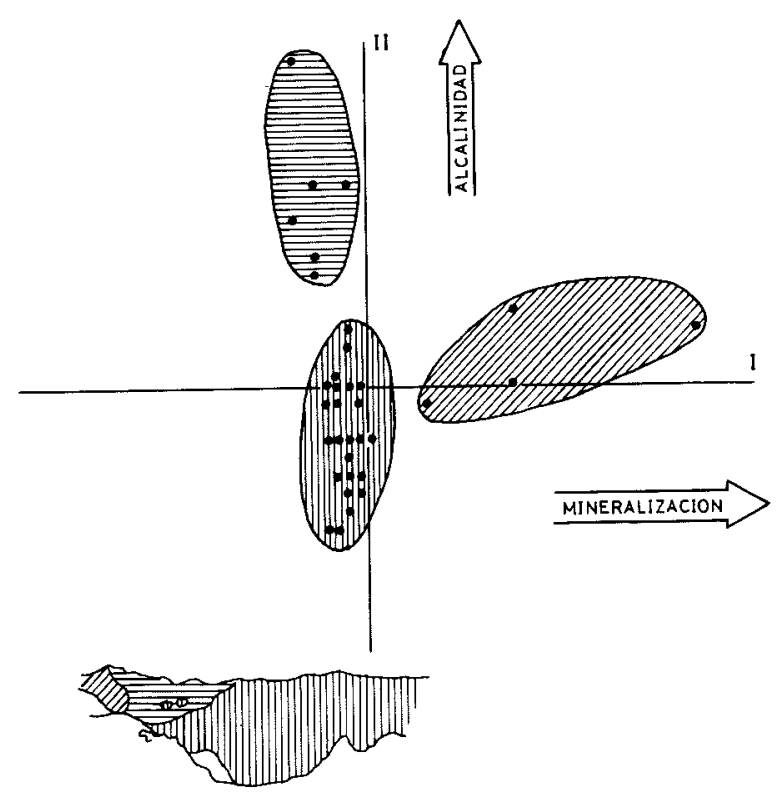

DIZA SECTOR 1: DESCARGA REGIONAL SECTOR 3 : DESCARGA INTERMEDIA IIIII) SECTOR 2: RAÑA SECTOR 4: DESCARGA LOCAL Y

Figure 2. Evolution trends in the groundwater of the Madrid aquifer and their correspondence with aquifer sectors. Each of the first prinand their correspondence with aquifer sectors. Each of the first prion trends. Component I materializes "mineralization", consisting of a global increase of the dissolved mineral elements, especially chloride and increase of the dissolved component II corressodium, taking place in regional discharges. Component ponds to the "alkalinization" trend, resulting in a steady replacement of calcium by sodium, $\mathrm{pH}$ increase and carbonate enrichment, taking place in the intermediate discharges (from BESTEIRO, 1992). gement can be obtained from the characterization of the geohydrological system in which the wetland is located, hydrochemistry, flooding regime, biological communities, etc., the water balance is necessary for the complete understanding of the wetland as an ecosystem. The weakest points of a wetland water balance are 1)the estimation of evapotranspiration and 2)the subterranean in or out flows representing water exchanges with both saturated and unsaturated ground. As the work of BESTEIRO (1992) on the Madrid aquifer wetlands shows, some interesting conclusions may be reached even in the absence of replicated, sophisticated equipment to cover every wetland surveyed.

The water balance types of the wetlands in this aquifer are closely associated with the main relief regions differentiated on its surface. The most dissected area by the drainage network (resulting from upward moving erosion from the Tagus system) is characterized by the scarcity of discharge wetlands that are much more abundant in the poorly drained, flatter areas of the lower aquifer levels (GONZALEZ BERNALDEZ et al., 1987; BESTEIRO, 1992).

Groundwater relationships greatly affect parameters such as basin morphometry, mineralization, turbidity and flooding regime. Basin morphometry can be characterized by the following main patterns:

- "Ojos" or rounded, deep basins without "littoral" plains. Characteristic of the local and intermediate groundwater discharge systems.

- Irregular and shallow shapes characterize the regional groundwater discharge areas.

- Round and shallow basins with "littoral" plain are characteristic of recharge areas.

The relationships between hydrochemistry and geohydrology are also clear cut:

- Hyposaline sodium-chloride waters characterize regional discharges.

- Subsaline sodium-bicarbonate water characterize the intermediate flow systems.

- Fresh calcium-bicarbonate water is characteristic of the recharge and local discharge areas.

The action of sub-surficial water may be very important. It is indicated by high $\mathrm{SiO}_{2}$ content due to silicate hydrolysis after the passage of the "hypodermic" water through the substrate. This phenomenon may help to differentiate subsurficial from meteoric water flows (BESTEIRO, 1992).

Recharge wetlands are more eutrophic and turbid than discharge wetlands.

Water balances clearly show the predominant entry of groundwater in "hypogenic" wetlands (after Del Villar's terminology) during the hydrologic cycle resulting in a 
Table 2. Plant indicators of groundwater chemistry: Corrected frequency profiles of discharge-habitat species as related to groundwater $\mathrm{pH}$. Only species with mutual information $\geq 0,1$ and corrected frequency $\geq 1.2(\mathrm{x} 100)$ are included (from GONZALEZ BERNALDEZ et al., 1989 a, modified). \pm signifies indifferent sensitivity to the factor class (corrected frecuency between 0.8 and 1.2).

\begin{tabular}{|c|c|c|c|c|c|}
\hline \multirow{2}{*}{$\overline{\text { Poa trivialis }}$} & \multirow[b]{2}{*}{332} & \multicolumn{3}{|c|}{$\begin{array}{c}\text { Class intervals } \\
7.350 / 7.355 / 7.900 / 8.025 / 8.125 / 8.365\end{array}$} & \\
\hline & & & & & \\
\hline Cynosurus cristatus & 308 & \pm & & & \\
\hline Senecio jacobaea & 277 & \pm & & & \\
\hline Holcus lanatus & 222 & \pm & & & \\
\hline Trifolium fragiferum & 217 & \pm & & & \\
\hline Carex divisa & 134 & \pm & \pm & & \\
\hline Juncus inflexus & 303 & 141 & & & \\
\hline Alopecurus arundinaceus & 249 & 174 & & & \\
\hline Lolium perenne & 239 & 183 & & & \\
\hline Trifolium repens & 233 & 167 & & & \\
\hline Galium verum & 221 & 131 & \pm & & \\
\hline Hypochaeris radicata & 208 & 125 & & & \\
\hline Daucus carota & 195 & 169 & & & \\
\hline Poa pratensis & 194 & 139 & \pm & & \\
\hline Potentilla reptans & 211 & 244 & & & \\
\hline Agrostis castellana & 208 & 221 & & & \\
\hline Hieracium pilosella & 192 & 181 & & & \\
\hline Convolvulus arvensis & 172 & 216 & & & \\
\hline Eryngium campestre & 150 & 183 & \pm & & \\
\hline Scirpus holoschoenus & 136 & 171 & \pm & & \\
\hline Cichorium intybus & 130 & 209 & \pm & & \\
\hline Dactylis glomerata & \pm & 270 & & & \\
\hline Plantago maritima & & 144 & 139 & 136 & \\
\hline Juncus maritimus & & & 171 & 172 & 168 \\
\hline Suaeda vera & & & & 504 & \pm \\
\hline Artemisia coerulescens & & & & 579 & \\
\hline Aeluropus littoralis & & & \pm & 344 & 164 \\
\hline Puccinellia festuciformis & & & \pm & 173 & 164 \\
\hline Convolvulus lineatus & & & \pm & 172 & 223 \\
\hline
\end{tabular}

extended flooding period, while this cycle is superficial and ephemeral in the "epigenic" wetlands. The flooding duration of the recharge wetlands, however, can be prolonged by occasional discharges of sub-surficial, silica-rich water. Groundwater discharge takes place when the piezometric level in its vicinity is higher than the water level in the waterbody. Both groundwater and sub-surficial, hypodermic water play an important role in buffering wetland water levels, increasing their stability. Figure 3 indicates the relationships between piezometer and water levels in the Ojo del Bravo hypogenic wetland Toledo). Water balance considerations reveal that groundwater discharge takes place as soon as the piezometer level exceed the water level in the wetland.

\section{GROUNDWATER EVOLUTION AND WETLAND CHARACTERISTICS}

Figure 4 shows the relationship between maximum possible groundwater flow length (a measure of distance 


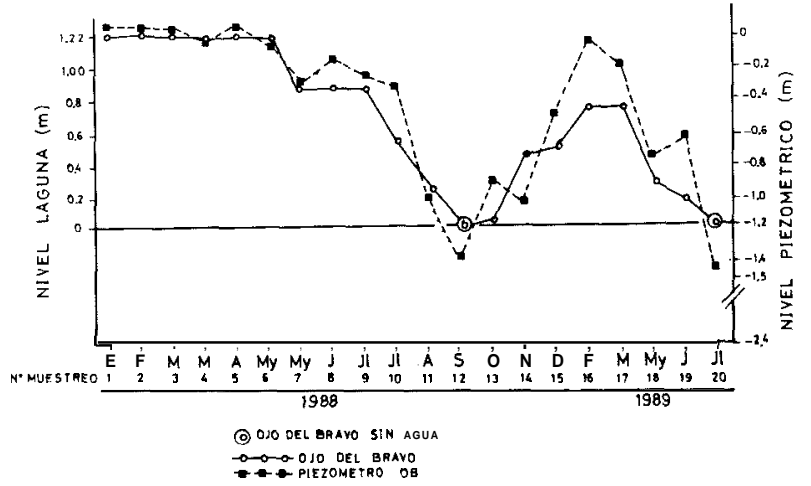

Figure 3. Relationships between piezometer oscillations and water levels in the Ojo del Bravo, a hypogenic wetland connected to the Madrid aquifer. The correlation between both magnitudes is apparent. Water balance considerations show that groundwater discharge takes place when piezometric values exceed water levels (from BESTEIRO, 1992).

between the upper level of the aquifer and the sampling point, taken perpendicularly to piezometric lines) and groundwater characteristics. Groundwater conductivity and $\mathrm{pH}$ have been selected as examples and the relationship has been obtained in the Los Arenales aquifer in the detritic Miocene deposits of the north Castillian subplateau. Although many other factors could help to distort this rela-

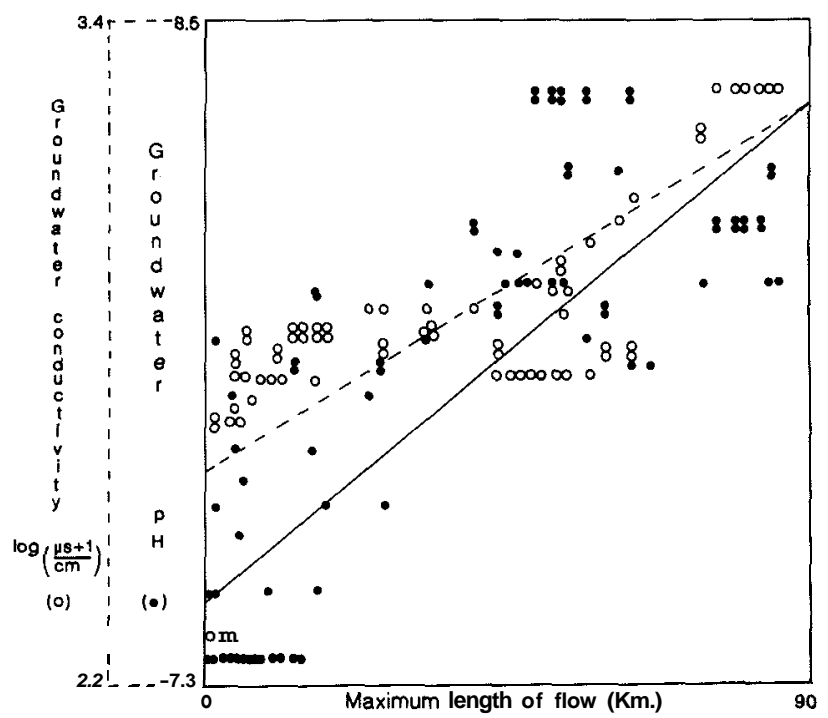

Figure 4. Relationships between "maximum flow length" an approximate measure of the maximum possible length of groundwater flows discharging in the area) and the chemical characteristics of groundwater affecting Los Arenales aquifer wetlands (Douro basin, North Castillian Plateau). Examples: Electrical conductivity and pH. Although other factors may influence groundwater hydrochemistry (Iithology, eventual short flows), flow length and therefore residence time of the groundwater are obviously the key factors controlling hydrochemistry in this aquifer (from REY BENAYAS eral.. 1990). tionship, this particular aquifer is characterized by a relatively uniform lithology in comparison with the water evolution effects. Flow length is proportional to residence time of groundwater in the aquifer (the curvature of the trajectories has been ignored), thus producing a rather close relationship between the flow length measure and water hydrochemistry.

An additional factor that could obscure the former relationship is the occasional existence of short flows in the whole aquifer area, including its lowest levels (groundwater will flow from small reliefs toward small discharge depressions forming the so called intermediate and local flow systems). However, the relatively flat geometry of the

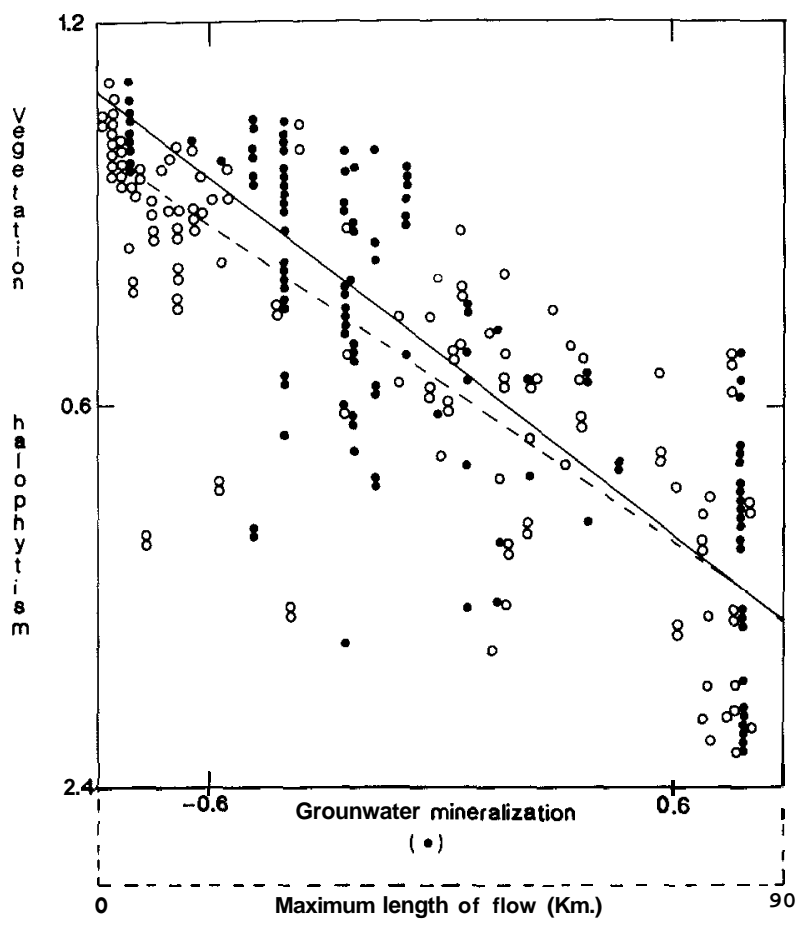

(o)

Figure 5. Relationship between "maximum flow length" (see Figure 4 for explanation), the first component of a Principal Component Analysis of grounwater chemical variables (labelled as groundwater mineralization) and wetland vegetation. Los Arenales aquifer (Douro basin, North Castillian Plateau). "Vegetation halophytism" is materialized by the first principal component of a vegetation matrix analysis. This first principal component is the most important vegetation variation trend and ordinates the wetland vegetation along a gradient from the most glycophytic to the extreme halophytic types. Halophytic vegetation types correspond to the longest groundwater flows (hence longer residence time and more prolonged water evolution in the aquifer) and vice versa. Correlation with "groundwater mineralization" is $r=0.813$; $\mathrm{p} \leq 0.01$, and correlation with "maximum legth of flow" is $\mathrm{r}=0.845$; $\mathrm{p} 10.01$ (from REY BENAYAS et al., 1990). 
Table 3. Plant indicators of groundwater chemistry: Corrected frequency profiles of discharge-habitat species as related to groundwater sodium (meq./1). Only species with mutual information 20.1 and corrected frequency $\geq 1.2$ ( $x 100$ ) are included (from GONZALEZ BERNALDEZ et al., 1989 a, modified). \pm signifies indifferent sensitivity to the factor class (corrected frecuency between 0.8 and 1.2).

Class intervals

$.285 / .435 / .530 / .700 / .885$

\begin{tabular}{lccc}
\hline \hline Festuca ampla & 540 & & \\
Trifolium pratense & 360 & \pm & \pm \\
Senecio jacobaea & 360 & \pm & \\
Potentilla reptans & 360 & \pm & \\
Juncus inflexus & 292 & \pm & \pm \\
Alopecurus arundinaceus & 270 & \pm & \pm \\
Agrostis castellana & 249 & \pm & \\
Galium verum & 236 & \pm & \\
Lolium perenne & 229 & 121 & \\
Carex divisa & 142 & 163 & \\
Poa trivialis & 302 & 161 & \\
Cynosurus cristatus & 279 & 169 & \pm \\
Trifolium repens & 216 & 142 & \\
Hypochaeris radicata & 176 & 182 & \\
Trifolium fragiferum & 172 & 150 & \pm \\
Poa pratensis & 168 & \pm & \\
Hieracium pilosella & 166 & & 395 \\
Festuca arundinacea & \pm & & 395 \\
Plantago maritima & & & 395 \\
Juncus maritimus & & & \\
Artemisia coerulescens & & \\
Aeluporus littoralis & & & \\
Suaeda vera & & & \\
\hline
\end{tabular}

aquifer section considered (seen in the endorrheic nature of many of the wetlands) minimizes these influences.

Regional flows can thus be considered as a key factor in controlling wetland hydrochemistry in this area.

Figure 5 shows the relationship between "maximum flow length" and vegetation characteristics in the discharge wetlands. "Vegetation halophytism" is materialized by the first principal axis of a vegetation factor analysis. This first component is the most important variation trend of vegetation in the area and reflects a gradient from the most glycophytic (least halophylous) vegetation types to the most halophytic. It is apparent that the halophytic pole corresponds to the longest groundwater flows, i.e. the most aged and evolved water (more alkaline and mineralized). In addition, the relationship with "groundwater mineralization" a factor obtained by principal component analysis of groundwater-chemical variables is presented in the same figure. It is apparent that correlation between this factor and plant "halophytism" is even better.
Table 4. Relationships between groundwater content in some ions and the same ions extracted from wetland soils in Los Arenales aquifer, Douro basin, northern Castilian subplateau. PCA Factors I and II refer to principal components of factor analysis performed with groundwater and soil chemical variables respectively (from GONZALEZ BERNALDEZ \& REY BENAYAS, 1992a)

\begin{tabular}{lc}
\hline & $r$ \\
\hline $\mathrm{SO}_{4}^{2-}$ & .663 \\
$\mathrm{I}$ Factor PCA & .651 \\
Conductivity & .626 \\
$\mathrm{Mg}^{2+}$ & .576 \\
$\mathrm{pH}$ & .504 \\
$\mathrm{Ca}^{2+}$ & .443 \\
$\mathrm{Na}^{2+}$ & .406 \\
${\mathrm{II} \mathrm{Factor} \mathrm{PCA}^{-}}_{\mathrm{CO}_{3}{ }^{2-} \mathrm{HCO}_{3}^{-}}$ & .389 \\
$\mathrm{CO}_{3}{ }^{-}$ & .310 \\
$\mathrm{HCO}_{3}^{-}$ & .267 \\
\hline
\end{tabular}




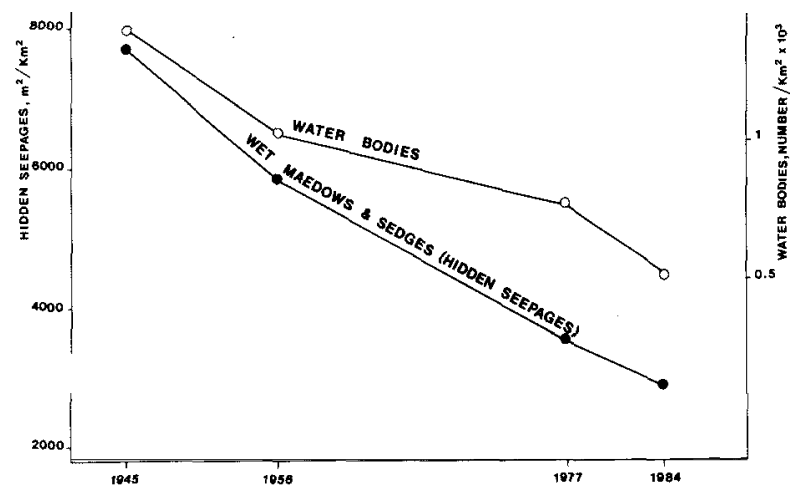

Figure 6. Changes in the numher of waterbodiea and hidden seepage wetlands due to groundwater withdrawal and drainage during the period 1945-1984. Los Arenales aquifer, Douro basin, northern Castillian Plateau (from GONZALEZ BERNALDEZ et al. . 1992b).

Tables 1 to 3 cover the same area and represent the correspondence between indicator wetland plants and some hydrochemical characteristics of the groundwater. Mutual information is a non-metric statistical procedure (GODRON, 1968) that indicates the tendency of two phenomena to coocurre, in this case the presence of the plant indicator and the different intensity levels of a physico-chemical factor. Table 1 shows the responses of discharge-habitat vegetation to groundwater electrical conductivity. The different plants vary greatly in their responses and some reliable conductivity indicators can be disclosed. Tables 2 and 3 show the same kind of relationship for discharge-habitat plants, groundwater $\mathrm{pH}$ and groundwater sodium respectively.

As already indicated, ageing and evolution of groundwater are more difficult to observe in limestone and evaporiterich aquifers due to the speed of the process (FREEZE \& CHERRY, 1979).

Table 4 shows the relationships between groundwater and soil chemical properties in discharge areas. It is apparent that some soil ions are very much affected by groundwater chemistry than others. The most mobile ions such as chloride and sodium tend to accumulate in deeper parts of the soil profile thus obscuring the correlation when constant depth samples $(20 \mathrm{~cm})$ are unaffected.

\section{GROUNDWATER WITHDRAWAL AND WETLAND CONSERVATION}

In semiarid regions where groundwater is heavily used for irrigation purposes, aquifer depletion and lowering of the upper surface of the saturated zone are serious threats to wetland conservation.
The previously discussed Tablas de Daimiel case is a dramatic example of this kind of damage. Very recently (1992), the Expert Commission named to assess the Doñana environmental issues strongly recommended the reduction of the irrigation scheme of El Rocío, which threatens essential groundwater levels for the maintenance of Doñana ecosystems (LLAMAS, 1988).

Along with these famous cases, there are thousands of less known incidents and conflicts between groundwater use and wetland conservation in the whole Spanish territory. The most important sources of impact involving groundwater management are:

- Water withdrawal from aquifers, especially for irrigation purposes. This kind of impact affects the non-saline wetlands associated with non-mineralized groundwater flow systems.

- Various forms of drainage, especially trench excavation, affecting many hidden seepages and saline wetlands (Villafáfila, Zamora; El Raso de El Portillo, Aldeamayor de San Martín, Valladolid, etc.)

Other serious types of impact such as pollution or dilution of saline waterbodies by water percolating from irrigated fields (Chiprana, Zaragoza) are not corrected to groundwater relationships and consequently are not considered here.

Figure 6 shows the changes in wetland abundance in the Los Arenales aquifer region on the northern Castillian subplateau. About $60 \%$ of the wetland area has been destroyed from 1945 to 1984 (extreme dates of the air photographs available for this study).

Table 5 indicates the modalities of impacts due essentially to the forementioned influences of trench drainage and groundwater pumping for irrigation. It can be observed that the type of the wetland connection with the natural groundwater system plays an important role in determining the nature of the impacts. It is apparent that recharge wetlands and wetlands depending on shallower superficial aquifers such as aeolian sands or "rañas" are least affected by groundwater withdrawal.

"Piezometric" lakes on very permeable ground receiving groundwater from the regional aquifer such as the Lagunas Reales near Medina del Campo were the first to disappear (about 1985), and have left almost no traces. The Lagunas were very famous waterfowl hunting areas already known by the ancient falconers and were remarkable enough to be described in the "Viaje de España" (Journey throughout Spain) by Antonio Ponz (1783) as proof of the possibility of converting the arid landscape of Central Spain into moist, water-rich territory. In contrast, the alkaline "bodones" or 
Table 5. Correspondence between wetland characteristics and types of impacts due to groundwater withdrawal and drainage. Los Arenales aquifer, Douro basin, northern Castillian subplateau (from GONZALEZ BERNALDEZ et al., 1992b).

\begin{tabular}{|c|c|c|c|c|c|}
\hline \multicolumn{2}{|c|}{$\begin{array}{l}\text { Wetland types based } \\
\text { on relationshiops with } \\
\text { the main aquifer }\end{array}$} & $\begin{array}{l}\text { Geology and } \\
\text { topography }\end{array}$ & $\begin{array}{l}\text { "Hidden seepages" } \\
\text { (wet meadows) }\end{array}$ & Waterbodies & $\begin{array}{l}\text { Nature of impacts and } \\
\text { interferences }\end{array}$ \\
\hline \multicolumn{2}{|c|}{ 1. Recharge wetlands } & $\begin{array}{l}\text { High, relatively flat } \\
\text { interfluves, detrital } \\
\text { Miocene }\end{array}$ & & $\begin{array}{l}\text { Small, roughly } \\
\text { circular, ephemeral } \\
\text { water holes, often } \\
\text { forming clusters. Very } \\
\text { sharp borders without } \\
\text { true phreatophytic } \\
\text { belts }\end{array}$ & $\begin{array}{l}\text { Not affected by } \\
\text { groundwater } \\
\text { withdrawal. } \\
\text { Occasional tillage } \\
\text { during droughts. }\end{array}$ \\
\hline \multicolumn{2}{|c|}{$\begin{array}{l}\text { 2. Wetlands not } \\
\text { connected with the } \\
\text { main aquifer }\end{array}$} & $\begin{array}{l}\text { Related to Pliocene } \\
\text { outwash deposits }\end{array}$ & $\begin{array}{l}\text { Small seepages in the } \\
\text { contact with Miocene } \\
\text { materials. } \\
\text { Glycophytes }\end{array}$ & $\begin{array}{l}\text { Generally ephemeral, } \\
\text { sometimes controlled } \\
\text { by autonomus small } \\
\text { perched aquifers } \\
\text { Glycophytes and } \\
\text { oxyphytes }\end{array}$ & $\begin{array}{l}\text { Not affected by } \\
\text { groundwater } \\
\text { withdrawal. } \\
\text { Occasional drainage }\end{array}$ \\
\hline \multicolumn{2}{|l|}{ id. } & $\begin{array}{l}\text { Related to Quternary } \\
\text { (aeolian) sand } \\
\text { deposits }\end{array}$ & $\begin{array}{l}\text { Small seepages in the } \\
\text { contact with } \\
\text { underlying Miocene } \\
\text { materials. } \\
\text { Glycophytes }\end{array}$ & & $\begin{array}{l}\text { Not affected by } \\
\text { groundwater } \\
\text { withdrawal }\end{array}$ \\
\hline \multirow{4}{*}{ 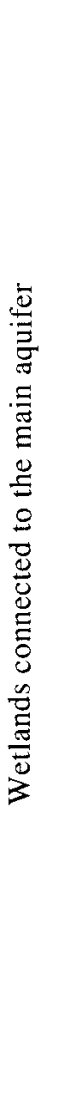 } & $\begin{array}{l}\text { 3.1. Wetlands } \\
\text { connected with } \\
\text { local flow } \\
\text { systems }\end{array}$ & $\begin{array}{l}\text { On relatively steep } \\
\text { pediment slopes and } \\
\text { alluvial fans, coarse } \\
\text { detrital Pliocene } 3.1\end{array}$ & $\begin{array}{l}\text { Very narrow, incise } \\
\text { discharges, } \\
\text { accopanied by } \\
\text { elongated meadows } \\
\text { Glycophytes }\end{array}$ & $\begin{array}{l}\text { springs and more or } \\
\text { less ephemeral } \\
\text { watercourses }\end{array}$ & $\begin{array}{l}\text { Not affected by } \\
\text { groundwater } \\
\text { withdrawal (taking } \\
\text { place in lower areas) }\end{array}$ \\
\hline & $\begin{array}{l}\text { 3.2. Wetlands } \\
\text { connected with } \\
\text { intermediate or } \\
\text { subregional } \\
\text { flow systems }\end{array}$ & $\begin{array}{l}\text { On generally flatter } \\
\text { areas, Miocene, } \\
\text { relatively fine textures }\end{array}$ & $\begin{array}{l}\text { More diffuse, less } \\
\text { narrow meadows. } \\
\text { Groundwater slightly } \\
\text { mineralized give rise } \\
\text { to subhalophytes } \\
\text { meadows. } \\
\text { Characteristic plots } \\
\text { mosaic. } \\
\text { Soloniets }\end{array}$ & $\begin{array}{l}\text { From tolerant to } \\
\text { alkalinophytes, } \\
\text { subhalophytes flooded } \\
\text { areas and potholes }\end{array}$ & $\begin{array}{l}\text { seepages: } \\
\text { - top soil } \\
\text { salinization, } \\
\text { xerohalophytes } \\
\text { - A horizon erosion } \\
\text { by wind } \\
\text { - potholes and small } \\
\text { lakes become } \\
\text { ephemeral retaining } \\
\text { meteoric water due to } \\
\text { impermeable solonetz } \\
\text { horizon }\end{array}$ \\
\hline & & $\begin{array}{l}\text { On Miocene covered } \\
\text { with shallow sand } \\
\text { deposits or coarser } \\
\text { textures }\end{array}$ & id. & id. & $\begin{array}{l}\text { - Vegetation changes } \\
\text { to therophy tes } \\
\text { - Potholes and lakes } \\
\text { dry out and do not } \\
\text { recover }\end{array}$ \\
\hline & $\begin{array}{l}\text { 3.3. Wetlands } \\
\text { connected with } \\
\text { regional flow } \\
\text { systems }\end{array}$ & & $\begin{array}{l}\text { Extensive meadows } \\
\text { with ameboid } \\
\text { contours. Saline } \\
\text { evaporating surfaces } \\
\text { forming interstitial } \\
\text { evaporites } \\
\text { Halophytes }\end{array}$ & $\begin{array}{l}\text { Small saline sloughs } \\
\text { alternating with } \\
\text { hummocks (silt dunes, } \\
\text { "lunettes") } \\
\text { Halophytes }\end{array}$ & $\begin{array}{l}\text { - No groundwater } \\
\text { withdrawal due to } \\
\text { insuitability for } \\
\text { agriculture } \\
\text { - Extensive drainage } \\
\text { works leading to } \\
\text { vegetation changes } \\
\text { (xerohalophytes) }\end{array}$ \\
\hline
\end{tabular}


"lavajos" with dispersed clay, rather impermeable bottom may still collect occasional meteoric water although they are no longer connected with the main aquifer. On the other hand, the sticky and dense soloniets soil horizons accompanying them are usually an obstacle for ploughing or reclamation.

Vast areas of Spain have been affected by groundwater extraction (both central subplateaus, La Mancha and western Andalusia are perhaps the most affected areas). Drainage water disposal is the main threat to the steppe lakes in Aragon. "Reclamation" and irrigated agriculture is universal, permanent source of impact for all wetlands.

\section{ACKNOWLEDGEMENTS}

This research has been funded by CAYCIT project NAT. 90-0721-C 02-01

\section{REFERENCES}

BESTEIRO, A.G. 1992. Limnología de las formaciones palustres situadas sobre el acuífero de Madrid; Análisis de relaciones entre aguas superficiales y subterráneas. Tesis doctoral, Facultad de Ciencias, Universidad Autónoma. Madrid.

DEPARTAMENTO DE ECOLOGIA, U.A.M. 1991. Restauración del territorio afectado por las operaciones de extracción de áridos en El Piul de Rivas (Madrid).Pioneer S.A. Madrid. Universidad Autónoma de Madrid.

FREEZE, R. A. \& J.A. CHERRY. 1979. Groundwater. Prentice Hall. New Jersey.

GONZALEZ BERNALDEZ, F. 1987. Las zonas encharcables: El marco conceptual. En: Bases Científicas para la protección y Gestión de los humedales en España. Real Academia de Ciencias Matemáticas, Físicas y Naturales. Madrid: 9-30.

GONZALEZ BERNALDEZ, F. 1988. Typology of wetlands of arid and semiarid regions. Proc. Int. Sympos. on the Hydrology of Wetlands in Semiarid and Arid Regions:

GONZALEZ BERNALDEZ, F. 1992. Los paisajes del agua: Terminología popular de los humedales (En prensa).

GONZALEZ BERNALDEZ, F., P. HERRERA, A. SASTRE, A., J.M. REY \& R. VICENTE. 1987. Comparación preliminar de los ecosistemas de descarga de aguas subterráneas en las cuencas del Duero y del Tajo. Hidrogeología y Recursos Hidráulicos, 11: 19-39.

GONZALEZ BERNALDEZ, F., C. MONTES, P. HERRERA \& A. SASTRE. 1988. Genetical typology of the Madrid aquifer wetlands. Proc. Intern. Sympos. on the Hydrology of Wetlands in Semiarid and Arid Regions:

GONZALEZ BERNALDEZ, F., J.M. REY, C. LEVASSOR \& B. PECO. 1989a. Landscape ecology of uncultivated lowlands in central Spain. Landscape Ecology, 3(1): 3-18. GONZALEZ BERNALDEZ, F., C. MONTES, A.G. BESTEIRO, P. HERRERA \& C. PEREZ. 1989b. Los hume dales del acuífero de Madrid. Canal de Isabel II. Madrid. GONZALEZ BERNALDEZ, F., B. PECO, C. LEVASSOR, A. LLORCA \& J. COMPAN. 1989c. La dehesa de Colmenar. Aula de Ecología. Ayuntamiento de Colmenar Viejo. Madrid.

GONZALEZ BERNALDEZ, F. \& J.M. REY BENAYAS. 1992a. Geochemical relationships between groundwater and wetland soils and vegetation in central Spain. Geoderma (In press).

GONZALEZ BERNALDEZ, F., J.M. REY BENAYAS \& A. MARTINEZ. 1992b. Typology of impacts produced by groundwater extraction. Journal of Hydrology (In press).

GODRON, M. 1968. Quelques applications de la notion de fréquence en écologie végétale. Oecologia Plantarum, 3: 185-212.

GROOTJANS, A. P. 1985. Changes of groundwater regime in wet meadows. Proefschrift ter vekrijging van het doktoraat. Rijksuniversiteit te Groningen.

HERRERA, P. 1987. Aspectos ecológicos de las aguas subterráneas en la facies arcósica de la cuenca de Madrid. Tesis doctoral. Universidad de Alcalá de Henares.

HUBBERT, M.K. 1940. The theory of groundwater movement. Jr. Geol., 48 : 785-944.

LLAMAS, M.R. 1982. Notas sobre peculiaridades de los sistemas hídricos de las zonas húmedas. En: Las Zonas Húmedas de Andalucía. Dirección General de Medio Ambiente, MOPU, Madrid: 77-85.

LLAMAS, M.R. 1988. Conflicts between wetland conservation and groundwater explotation: two case histories in Spain. Environmental Geol. Water Sci., 1(3): 241-251.

REY BENAYAS, J.M. 1989. Ecosistemas de descarga de acuíferos de la cuenca del Duero. Tesis doctoral. Facultad de Ciencias. Universidad Autónoma. Madrid.

REY BENAYAS, J.M., C. PEREZ, F.G. BERNALDEZ \& M. ZABALETA. 1989. Tipología y cartografía de los humedales de las cuencas del Duero y Tajo. Mediterranea. Sec. Biol. 12: 5-26. 
REY BENAYAS, J.M., F.G. BERNALDEZ, C. LEVASSOR \& B. PECO. 1990. Vegetation of groundwater discharge sites in the Douro basin, central Spain. J.Vegetation Science, 1: 461-466.
TOTH, J. 1963. A theoretical analysis of groundwater flow in small drainage basins. J. Geophys. Res., 68: 4795-4812. WINTER, T.C. 1981. Effects of the water table configuration in seepage through lake beds. Limnol. Ocenogr., 26: 925-934. 